\title{
Title: Sero-Prevalence of Covid-19 among workers in Malaysia
}

\author{
Authors \\ Aziyati binti Omar, BSc \\ Ishmah Hana Isharudin, BSc \\ Riasah Idris, BSc \\ Yukie Chem, BSc \\ Intan Surianne Mat Sahat, MLT \\ Selvanesan Sengol, BSc \\ Zirwatul Adilah Aziz, BSc \\ Zhuo-zhi Lim, MBBS \\ Teck-Onn Lim, FRCP
}

Noorliza Mohamad Noordin, MPA(Harvard)

\section{Author Affiliations:}

National Public Health Laboratory (NPHL) Malaysia (Noorliza Mohamad Noordin, Aziyati binti Omar, Ishmah Hana Isharudin, Riasah Idris, Yukie Chem, Intan Surianne Mat Sahat, Selvanesan Sengol, Zirwatul Adilah Aziz)

Healthy Malaysia Society (Zhuo-zhi Lim, Teck-Onn Lim)

\section{Corresponding Author:}

Teck Onn Lim

Email: limteckonn@gmail.com

Address: D7-3-1, Pusat Perdagangan Dana 1, Jalan PJU 1A/46, 47301 Petaling Jaya, Selangor, Malaysia

\begin{abstract}
From the beginning of the pandemic in Feb 2020, Malaysia has been through 4 waves of outbreak, the magnitude of each wave is several orders larger than the preceding one. By the end of the fourth wave in October 2021, Malaysia has among the highest death toll in Asia, cumulative incidence of confirmed cases has reached 7.0\% (>30\% in Klang Valley). However it remains uncertain what is the true proportion of the population infected.

We conducted a sero-survey on 1078 workers from 17 worksites in Klang Valley and Perak between July and September 2021. We tested them for SARS-CoV-2-specific antibodies using Ecotest, a lateral flow immunoassay (LFIA). The ability of antibody testing to detect prior infection depends on the assay and sero-reversion. We therefore adjusted the prevalence estimates to correct for potential misclassification bias due to the use of LFIA and seroreversion using test sensitivity and specificity results estimated from an independent validation study.

The mean age of the workers was 32 years, $89 \%$ were male and migrant workers comprised $81 \%$ of all subjects, $59 \%$ the subjects were from Klang valley. $33 \%$ of workers had prior RTPCR confirmed Covid-19 infections. We estimated 82.2 percent of workers had been infected by Covid-19 by July-September 2021. Prevalence was $99.9 \%$ among migrant workers and $12.1 \%$ among local workers. Klang Valley, the most industrialized region in Malaysia where most migrant workers are found, had $100 \%$ prevalence, giving an infection-to-case ratio (ICF) of $\sim 3$.

Our sero-prevalence results show that the incidence of Covid19 is extremely high among migrant workers in Malaysia, consistent with findings from other countries such as Kuwait and Singapore which also hosted large number of migrant workers.
\end{abstract}

\section{Keywords}

Serosurvey, Prevalence, Covid-19, Malaysia 


\section{Introduction}

Malaysia has emerged from the most recent wave of Covid-19 infection between June and October 2021 with among the highest death toll in Asia. By October 2021, just before the national lockdown was lifted, the cumulative incidence of confirmed Covid-19 had reached 75,550 per million population or $7.5 \%$ of the population [1] (Figures 1 and 2).

Figure 1: Cumulative confirmed Covid-19 cases per million people in ASEAN \& India

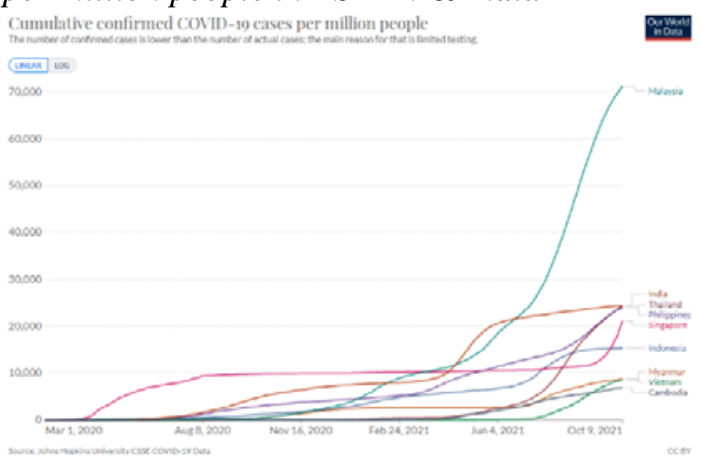

Figure 2: Cumulative confirmed Covid-19 deaths per million people in ASEAN \& India

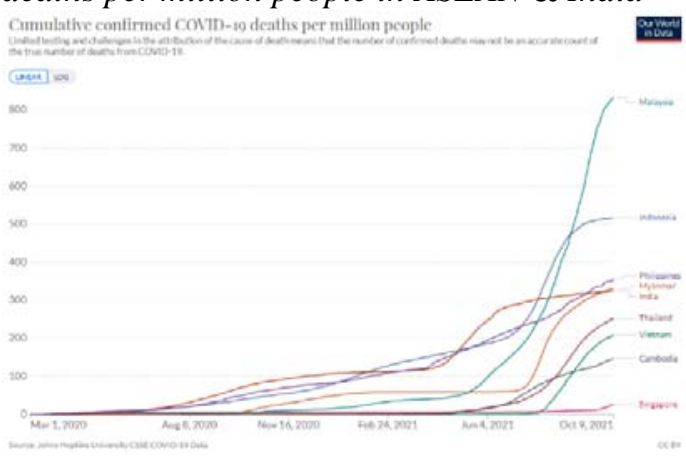

Covid-19 infection is often asymptomatic, as much as $40 \%$ of confirmed Covi19 according to one systematic review [2], and a large sero-survey in neighbouring Singapore showed 78\% of infected migrant workers had sub-clinical infection [3]. Hence, antibody testing in seroprevalence survey is necessary to provide information on past exposure to severe acute respiratory syndrome coronavirus 2 (SARS-CoV-2). This is useful for estimating the true burden of Covid-19, and for identifying at-risk groups, such as healthcare workers, migrant workers and nursing home residents. To date, three sero-prevalence studies $[4,5,6]$ have been conducted in Malaysia, as summarized in Table 1. These surveys have found remarkably low prevalence perhaps because they were conducted in 2020 early in the course of the Covid-19 epidemic in Malaysia.

\section{Table 1: Data on Sero-prevalence in Malaysia}

\begin{tabular}{|c|l|l|l|l|} 
\# & Study & $\begin{array}{l}\text { Antibody } \\
\text { assay }\end{array}$ & $\begin{array}{l}\text { Study Calendar time, location } \\
\text { \& population }\end{array}$ & $\begin{array}{l}\text { Prevalence } \\
\text { estimate }\end{array}$ \\
\hline 1. & $\begin{array}{l}\text { COVID-19 antibody } \\
\text { surveillance among healthcare } \\
\text { workers in a non-COVID } \\
\text { designated cardiology centre } \\
\text { [4] }\end{array}$ & $\begin{array}{l}\text { Lateral flow } \\
\text { immunoassay }\end{array}$ & $\begin{array}{l}\text { March 2020 } \\
\text { 310 healthcare workers in a } \\
\text { single hospital in Sarawak }\end{array}$ & $\begin{array}{l}\text { Age } \\
\text { standardized } \\
4.5 \%\end{array}$ \\
\hline 2. & $\begin{array}{l}\text { Low post pandemic wave } \\
\text { SARS-CoV-2 sero-prevalence } \\
\text { in Kuala Lumpur and Selangor, } \\
\text { Malaysia [5] }\end{array}$ & $\begin{array}{l}\text { Neutralizing } \\
\text { antibody } \\
\text { (cPass) }\end{array}$ & $\begin{array}{l}\text { January-June 2020 } \\
588 \text { stored serum samples at a } \\
\text { teaching hospital serving Kuala } \\
\text { Lumpur and Selangor }\end{array}$ & $0.4 \%$ \\
\hline 3. & $\begin{array}{l}\text { Serology surveillance of } \\
\text { SARS-CoV-2 antibodies } \\
\text { among healthcare workers in } \\
\text { COVID-19 designated facilities } \\
\text { in Malaysia [6] }\end{array}$ & $\begin{array}{l}\text { Neutralizing } \\
\text { antibody } \\
\text { (cPass) }\end{array}$ & $\begin{array}{l}\text { April- May 2020 } \\
400 \text { healthcare workers in } \\
\text { public hospitals in Kuala } \\
\text { Lumpur }\end{array}$ & $0.0 \%$ \\
\hline
\end{tabular}

An important community risk factor driving Covid-19 infection in Malaysia is the presence of large number of migrant workers, which comprise $22 \%$ of our labour force (3.5 million [7] out of 15.7 million in 2020 [8]). This is attested by numerous press reports on frequent occurrences of Covid-19 outbreaks at workplaces [9]. Singapore, a neighboring country, which also hosted large number of migrant workers, has reported infection rate of $56 \%$ among its workers in dormitories [10]. And Thailand, another neighboring country hosting large 
number of migrant workers, similarly attributed a recent surge in Covid-19 to new clusters at the country's largest shrimp market where numerous migrant workers are employed [11].

In this study, we provide estimates of the sero-prevalence of Covid-19 infection between June-September 2021 in Malaysia, and compare the prevalence between migrant and local workers.

\section{Methods}

The study sample for this sero-survey were subjects who participated in ongoing studies on worksite-based screening and vaccination between July and September 2021. They were recruited from 17 worksites, comprising 17 factories and 2 farms located in Federal Territory and Selangor (jointly named Klang valley) and Perak. The Ministry of Health's (MOH) Medical and Research Ethics Committee approved the study and all subjects gave informed consent.

These subjects had baseline SARS-CoV-2-specific antibodies tested as part of the studies. They were tested using Ecotest, a lateral flow immunoassay (LFIA). The LFIA test was performed according to the manufacturer's instructions and was conducted by trained nurses on finger-stick capillary samples taken from the participants.

The ability of antibody testing to detect prior infection depends on the assay, disease severity and timing of testing [12]. LFIA has lower sensitivity and specificity compared to lab-based ELISA test. We therefore validated the test performance of LFIA by repeat testing for a subset of 468 subjects (393 tested negative on LFIA, 75 tested positive) who also had neutralizing antibody assay (cPass GenScript Biotech). Using the neutralizing antibody assay as reference and $20 \%$ neutralization inhibition as cutoff, we determined the LFIA has a test sensitivity of $83 \%$ and specificity $96 \%$. Antibody levels will decay over time, and antibody response may be transient in mild or asymptomatic infection [13]. Sero-reversion may have occurred among some subjects; that is their antibody level may have dropped below the threshold for positivity at the time of entry into this study. We also determined the prior RTPCR confirmed Covid-19 status for a subset of 468 subjects. Using their prior RT-PCR test results as reference, we determined that antibody test at study entry has a sensitivity of $28 \%$. We use these estimates of test sensitivity and specificity to adjust the prevalence estimates of Covid-19, in order to correct for potential misclassification bias due to the use of LFIA and sero-reversion $[14,15]$.

\section{Results}

A total of 1078 workers participated in the sero-survey between July and September 2021. Table 1 shows the characteristics of all the participants. The mean age of the workers was 32 years, $89 \%$ were male and migrant workers comprises $81 \%$ of all subjects, $59 \%$ the subjects were from Klang valley. $33 \%$ of workers had prior RT-PCR confirmed Covid-19 infections.

We estimated 82.2 percent of workers had been infected by Covid-19 by June-September 2021. Prevalence was $99.9 \%$ among migrant workers and $12.1 \%$ among local workers. Klang Valley, the most industrialized area in Malaysia where most migrant workers are employed, had $100 \%$ prevalence while in Perak 55\% of migrant workers had prior exposure. 
medRxiv preprint doi: https://doi.org/10.1101/2022.01.16.22269388; this version posted January 17, 2022. The copyright holder for this preprint (which was not certified by peer review) is the author/funder, who has granted medRxiv a license to display the preprint in perpetuity.

It is made available under a CC-BY-NC-ND 4.0 International license .

Table 1: Characteristics of workers who participated in Covid-19 sero-survey, Malaysia July-September 2021

\begin{tabular}{|c|c|c|}
\hline & $\begin{array}{c}\text { Local } \\
\text { workers }\end{array}$ & $\begin{array}{l}\text { Migrant } \\
\text { workers }\end{array}$ \\
\hline Total number & 204 & 874 \\
\hline \multicolumn{3}{|l|}{ Demographic, No. (\%) } \\
\hline \multicolumn{3}{|l|}{ Age, year } \\
\hline Mean (SD) & $32(12)$ & $32(7)$ \\
\hline Median (IQR) & $28(23,40)$ & $32(27,38)$ \\
\hline \multicolumn{3}{|l|}{ Gender, No. (\%) } \\
\hline Male & $136(67 \%)$ & $823(94 \%)$ \\
\hline Female & $68(33 \%)$ & $51(6 \%)$ \\
\hline \multicolumn{3}{|l|}{ Ethnicity, No. (\%) } \\
\hline Malay & $77(38 \%)$ & NA \\
\hline Chinese & $120(59 \%)$ & NA \\
\hline Indian & $7(3 \%)$ & NA \\
\hline \multicolumn{3}{|l|}{ Location, No. (\%) } \\
\hline Federal Territory \& Selangor (Klang valley) & $129(63 \%)$ & $510(58 \%)$ \\
\hline Perak & $75(34 \%)$ & $364(41 \%)$ \\
\hline \multicolumn{3}{|l|}{ Prior RT-PCR confirmed Covid-19 } \\
\hline Total number & 75 & 393 \\
\hline No. (\%) positive & $0(0)$ & $198(50 \%)$ \\
\hline
\end{tabular}

Abbreviation: NA Not applicable

Table 2: Sero-prevalence estimates among workers in Malaysia, July to September 2021

\begin{tabular}{|c|c|c|}
\hline & $\begin{array}{c}\text { Local } \\
\text { workers }\end{array}$ & $\begin{array}{l}\text { Migrant } \\
\text { workers }\end{array}$ \\
\hline Total number & 204 & 874 \\
\hline \multicolumn{3}{|l|}{ Unadjusted estimate, \% (95\% CI) } \\
\hline Overall & $\begin{array}{c}4.4 \% \\
(2.3,8.3) \\
\end{array}$ & $\begin{array}{c}23.8 \% \\
(21.1,26.7) \\
\end{array}$ \\
\hline $\begin{array}{r}\text { Klang valley } \\
\text { (Federal Territory and Selangor) }\end{array}$ & $\begin{array}{c}4.6 \% \\
(2.1,10.0)\end{array}$ & $\begin{array}{c}30.8 \% \\
(26.9,34.9)\end{array}$ \\
\hline Perak & $\begin{array}{c}4.0 \% \\
(1.3,11.7) \\
\end{array}$ & $\begin{array}{c}14.0 \% \\
(10.7,17.9) \\
\end{array}$ \\
\hline \multicolumn{3}{|l|}{$\begin{array}{l}\text { Estimate adjusted for Sero-reversion } \\
\text { and test performance, \% }(95 \% \mathrm{CI})\end{array}$} \\
\hline Overall & $\begin{array}{c}12.1 \% \\
(8.0,16.2) \\
\end{array}$ & $\begin{array}{c}99.9 \% \\
(96.7,100) \\
\end{array}$ \\
\hline $\begin{array}{r}\text { Klang valley } \\
\text { (Federal Territory and Selangor) }\end{array}$ & $13.0 \%$ & $\begin{array}{c}100 \% \\
(-)\end{array}$ \\
\hline Perak & $10.3 \%$ & $55.0 \%$ \\
\hline
\end{tabular}




\section{Discussion}

From the beginning of the pandemic in Feb 2020, Malaysia has been through 4 waves of outbreak, the magnitude of each wave is several orders larger than the preceding one. By the end of the fourth wave in October 2021, we have among the highest death toll in Asia [1], cumulative incidence of confirmed cases has reached 7.0\% [1] (>30\% in Klang Valley) [16]. Consistent with this, we reported here a sero-prevalence of 99\% among migrant workers, $100 \%$ in Klang Valley, giving an infection-to-case ratio (ICF) of $\sim 3$ in contrast to the ICF in India of 56.2 [17].

Our result is also consistent with findings from similar countries hosting large number of migrant workers, though more extreme. Kuwait, a Gulf country hosting large number of migrant workers who accounted for $>60 \%$ of confirmed cases, reported a sero-prevalence of $38.1 \%$ in May-June 2020 [18]. In neighbouring Singapore, migrant workers who lived in dormitory accounted for $90 \%$ of infections there [19], and a large study in December 2020 found a prevalence of 56\% [3], no doubt higher by now.

Malaysia has long been warned that its large number of migrant workers, many of whom are undocumented illegals, working and housed in crowded unhygienic condition, will pose a serious risk of recurrent outbreaks [20,21]. Migrant workers are mostly young healthy adults, a very high percentage of them have asymptomatic infections, thus becoming an important source of transmission in the community $[22,23]$. Our results show that this has come to pass.

And yet, we have turned a blind eye to this, unable to formulate effective policy to address the risk, simply because there are too many vested interests involved. The Malaysian economy, especially the manufacturing, construction, agriculture and catering sectors, has become heavily dependent on low cost migrant labour to stay afloat. The supply of migrant labour to private employers has itself become a huge industry, and a highly lucrative source of income to politicians and government officers who control issuance of the labour import license, while street bureaucrats like police and immigration officers preyed on employers and migrant workers for bribes. Under such circumstances, it is not surprising that public health interest will take a back seat.

This study has limitations.

- We have used a convenient sample which is not representative of the workers' population. Given the nature of the migrant labour industry where illegal practices are widespread, there does not exist a national sampling frame to provide a random sample for the study. Indeed just recruiting 17 worksites to agree to participate was challenging. Participating worksites are therefore not likely to be representative of all worksites, they are likely to be more compliant in their labour practices and yet we found such high prevalence of Covid19.

- We have used LFIA to detect the presence of antibody. We have adjusted accordingly for the test imperfect sensitivity and specificity. We have also conducted an independent validation study to estimate the test sensitivity and specificity (rather than rely on manufacturer's reported results). The validation sample was the same as the subjects (workers) in this study, rather than another study population such as hospitalized patents.

- By July-September 2021, we are 20 month into the pandemic in Malaysia. Many workers are likely to have been infected earlier in the course of the epidemic and 
will likely have sero-reverted at the time of this study. Indeed we found a positive neutralizing antibody test has a sensitivity of only 28to detect prior exposure among subjects who previously had PCR confirmed Covid19. We have adjusted the estimate accordingly for sero-reversion.

\section{References}

1. Cumulative confirmed COVID-19 cases and deaths per million people. Published online at OurWorldInData.org. Retrieved from: 'https://ourworldindata.org/explorers/coronavirus-dataexplorer?

2. Qiuyue Ma, Jue Liu, Qiao Liu, et al. Global Percentage of Asymptomatic SARS-CoV-2 Infections Among the Tested Population and Individuals With Confirmed COVID-19 Diagnosis. A Systematic Review and Meta-analysis. JAMA Netw Open. 2021;4(12):e2137257. doi:10.1001/jamanetworkopen.2021.37257

3. Tan IB, Tan C, Hsu LY, Dan YY, Aw A, Cook AR, Lee VJ. Prevalence and Outcomes of SARSCoV-2 Infection Among Migrant Workers in Singapore. JAMA. 2021 Feb 9;325(6):584-585. doi: 10.1001/jama.2020.24071.

4. Ling HS , Pang IX, Fong AYY, Ong TK, Khiew NZ, Cham YL, et al. COVID-19 antibody surveillance among healthcare workers in a non-COVID designated cardiology centre. Authorea 2020 May 15 .

5. Sam IC, Chong YM , Tan CW , Chan YF . Low post pandemic wave SARS-CoV-2 seroprevalence in Kuala Lumpur and Selangor, Malaysia. J Med Virol 2020

6. Woon YL, Lee YL, Chong YM, Ayub NA, Krishnabahawan SL, Lau JFW, Subramaniam-Kalianan R, Sam IC, Chan YF, Sevalingam RK, Ramli A, Chuah CH, Mat-Hussin H, Leong CL, Chidambaram SK, Peariasamy KM, Goh PP. Serology surveillance of SARS-CoV-2 antibodies among healthcare workers in COVID-19 designated facilities in Malaysia. Lancet Reg Health West Pac. 2021 Apr;9:100123. doi: 10.1016/j.lanwpc.2021.100123.

7. Milton Lum. Covid-19 And Foreign orkers. https://codeblue.galencentre.org/2020/05/27/covid-19-andforeign-workers/

8. Department of Statistics Malaysia. Key Statistics of Labour Force in Malaysia, https://www.dosm.gov.my/v1/index.php?r=column/cthemeByCat\&cat=124\&bul_id=Y25FMFU4elNLSIVpb k5reVF2M3pWUT09\&menu id=U3VPMldoYUxzVzFaYmNkWXZteGduZz09

9. Workplace clusters are key source of Covid-19 infections in Malaysia. https://www.straitstimes.com/asia/seasia/workplace-clusters-are-a-key-source-of-covid-19-infections-in-malaysia

10. Tan IB, Tan C, Hsu LY, Dan YY, Aw A, Cook AR, Lee VJ. Prevalence and Outcomes of SARS-CoV-2 Infection Among Migrant Workers in Singapore. JAMA 2021;325: 584-585

11. Rojanaworarit C, El Bouzaidi S. International labour trafficking: A neglected social origin of COVID-19. Lancet Reg Health West Pac. 2021;8:100121. doi:10.1016/j.lanwpc.2021.100121

12. Peluso MJ, Takahashi S, Hakim J, et al. SARS-CoV-2 antibody magnitude and detectability are driven by disease severity, timing, and assay. Sci Adv. 2021;7(31):eabh3409. doi:10.1126/sciadv.abh3409

13. Long QX, Tang XJ, Shi QL, et al. Clinical and immunological assessment of asymptomatic SARSCoV-2 infections. Nat Med 2020; published online June 18. https://doi.org/10.1038/s41591-0200965-6.

14. Bendavid E, Mulaney B, Sood N, et al. COVID-19 antibody seroprevalence in Santa Clara County, California. medRxiv [Preprint] 2020. April 30. https://doi.org/10.1101/2020.04.14.20062463

15. Accorsi EK, Qiu X, Rumpler E, Kennedy-Shaffer L, Kahn R, Joshi K, Goldstein E, Stensrud MJ, Niehus R, Cevik M, Lipsitch M. How to detect and reduce potential sources of biases in studies of SARS-CoV-2 and COVID-19. Eur J Epidemiol. 2021 Feb;36(2):179-196. doi: 10.1007/s10654021-00727-7.

16. Lim TO. Transitioning To Endemic Covid-19: Is The Worst Behind Us? CodeBlue | 14 October 2021. Available at: https://codeblue.galencentre.org/2021/10/14/transitioning-to-endemic-covid19-is-the-worst-behind-us-dr-lim-teck-onn/

17. Chen X, Chen Z, Azman AS, Deng X, et al. Serological evidence of human infection with SARSCoV-2: a systematic review and meta-analysis. Lancet Glob Health 2021; 9: e598-609

18. Alali WQ, Bastaki H, Longenecker JC, Aljunid SM, AlSeaidan M, Chehadeh W, Vainio H. Seroprevalence of SARS-CoV-2 in migrant workers in Kuwait. J Travel Med. $2021 \mathrm{Feb}$ 23;28(2):taaa223. doi: 10.1093/jtm/taaa223. 
medRxiv preprint doi: https://doi.org/10.1101/2022.01.16.22269388; this version posted January 17, 2022. The copyright holder for this preprint

(which was not certified by peer review) is the author/funder, who has granted medRxiv a license to display the preprint in perpetuity.

It is made available under a CC-BY-NC-ND 4.0 International license.

19. Economist. Singapore's migrant workers have endured interminable lockdowns. June 192021. Available at: https://www.economist.com/asia/2021/06/19/singapores-migrant-workers-haveendured-interminable-lockdowns

20. Greenaway C, Hargreaves S, Barkati S, Coyle CM, Gobbi F, Veizis A, Douglas P. COVID-19: Exposing and addressing health disparities among ethnic minorities and migrants. J Travel Med. 2020 Nov 9;27(7):taaa113. doi: 10.1093/jtm/taaa113. PMID: 32706375; PMCID: PMC7454797.

21. Beech H. A Company Made P.P.E. for the World. Now Its Workers Have the Virus. The New York Times Dec. 20, 2020. Available at: https://www.nytimes.com/2020/12/20/world/asia/topglove-ppe-covid-malaysia-workers.html

22. Letizia AG, Ge Y, Vangeti S, et al. SARS-CoV-2 seropositivity and subsequent infection risk in healthy young adults: a prospective cohort study. Lancet Respir Med 2021; published online April 15. https://doi. org/10.1016/S2213-2600(21)00158-2.

23. SARS-CoV-2 reinfection in a closed setting: lessons for the community. Lancet Respir Med 2021 Published Online April 15, 2021 https://doi.org/10.1016/S2213-2600(21)00187-9] 